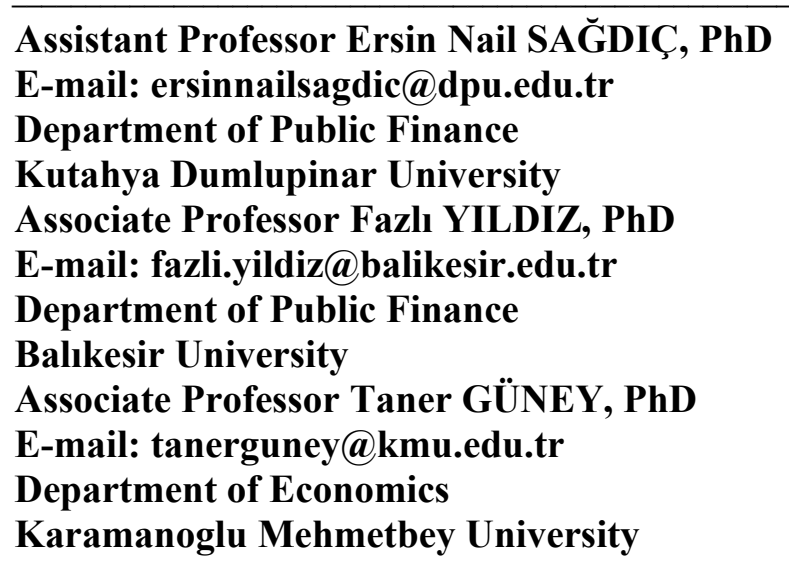

\title{
DOES DOMESTIC PUBLIC DEBT AFFECT FINANCIAL DEVELOPMENT? NEW EVIDENCE FROM CENTRAL AND EASTERN EUROPEAN ECONOMIES
}

Abstract. After the 1990s, economic, social, and political changes in transition economies have attracted attention through liberalization and EU integration. In this sense, the effects of liberalization policies and the effects of the economic activities of the state on the economy have been the subject of discussion. The aim of this paper was to investigate the effects of domestic public debt on financial development in Central and Eastern European countries using panel autoregressive distributed lag (ARDL) method for the period of 1994 to 2017 . This study fulfills a gap in the existing literature for Central and Eastern European countries on "safe assets" and the "lazy banks" views. The findings of the study provide evidence that public domestic debt harms financial markets in both the short and long run for these countries. The results strongly support the "lazy banks" view in these countries. The results of this research also reveal that the economic activities of the state through public domestic debt prevent the development and deepening of financial markets.

Keywords: Financial Development; Domestic Public Debt; Crowding-Out Effect; Lazy Banks; Safe Assets.

\section{JEL Classification: E62, H63, O16}

\section{Introduction}

In the field of public economy, the effect of public debt on financial development is analyzed from the perspective of public expenditures. Public expenditures are seen as a tool that fulfill only the basic functions of the state at a

DOI: $10.24818 / 18423264 / 55.4 .21 .10$ 
minimum level in the field of the economy until the 1929 Great Depression, with the effect of the classical economic view. Public expenditures have been ignored in economic policies because the view that the economic activities of the State should be at a minimum level within the "neutral state" approach was accepted in this period. After the Great Depression of 1929, the importance of public expenditures in economic and social policies gradually increased. Public expenditures have become not only a dynamic for economic growth but also an important tool in policies, such as realizing the distribution of income and wealth, ensuring equivalence in the balance of foreign payments, and ensuring economic stability. However, from the 1930s to the 1980 s, states failed to use public expenditures effectively. While using this tool, the State started to act like a private company in the economy This situation both harmed the private sector and slowed the development of technology and innovation.

As of the 1980s, the economic intervention of the State has been significantly reduced again with Reagan policies (Reaganomics) in the United States and Thatcher policies (Thatcherism) in the United Kingdom. Also, the view that economic crises, such as the 1973 Oil Crisis, were the main cause of inflation rather than the positive effect of public expenditures came to the agenda again. In this period, Milton Friedman, one of the pioneers of the Monetarist view, put forward the "Crowding-out effect" view. The crowding-out effect argues that financing public expenditures, through borrowing or printing money, causes high interest rates (Aschauner, 1989; Wang, 2005). Increasing interest rates will reduce the national income level by negatively affecting private-sector investment expenditures, consumption expenditures, exchange rate, and export level (Ersoy, 2012). It mainly focuses on the fact that the State, should play a role in the efficient distribution of resources and capital; this is also the aim of this study. In other words, without intervening in the market, the State should be an important intermediary on the financial markets, or that it should play a regulatory role (Janda and Kravtsov, 2017). In this way, both the negative effects of crowding out on the economy will decrease and the level of financial development will positively affect other economic areas.

With the rapid liberalization and EU integration after the 1990s, economic, social, and political changes have also started rapidly in Central and Eastern European countries. Therefore, the economic structures of these countries have attracted attention in the literature. The main question here is this: How did the integration and liberalization process affect the economies of these countries? Indeed, the financial development of these countries is low compared with other developed countries. On the contrary, the public debt levels of these countries were higher than other countries. This situation is explained in detail in the next section. Apart from its political reasons, in this way, the states try to achieve their primary goals such as increasing savings, ensuring growth and development. However, how this process affects other areas of the economy has become an essential area of research. The main objective of this study is to try to answer these questions by 
Does Domestic Public Debt Affect Financial Development? New Evidence from Central and Eastern European Economies

considering both the empirical and theoretical literature. For this purpose, despite the integration and liberalization policies, the effect of government debt on financial developments has been investigated in both the short and long term. With this aim, this paper examines the effects of public domestic debt on financial development in Central and Eastern European countries (Bulgaria, Croatia, Czechia, Estonia, Hungary, Latvia, Lithuania, Poland, Romania, Slovak Republic, and Slovenia) by using the panel ARDL method.

The study makes important contributions in several aspects of the existing literature. First of all, the lack of empirical study on the subject for these countries makes this study significant. Further, with this study, the short- and long-term coefficients and the direction of the impact of public domestic debt on financial development were determined on a per-country basis. Lastly, this study is also expected to make a significant contribution in determining the effect of the government's public debt policy implementation results on financial development for transition economies. This paper is structured as follows. Section 2 introduces the basic features and development of the financial development and public domestic debt for these countries. Section 3 presents the theoretical framework and an overview of literature. Section 4 explains the data and econometric methodology. Section 5 presents the empirical findings and discussion. Finally, Section 6 concludes the paper and draws policy implication in light of the empirical findings.

\section{Features of the Financial Development and Public Domestic Debt for Central and Eastern European Countries}

The socialist system, which continued its rule until the end of the 1980s, came to end with the collapse of the Berlin Wall separating socialist East Germany from capitalist Federal Germany. Countries continuing their economic activities in the socialist system evolved into a free market and capitalist order in the following period. These countries are characterized as economically and socially transition economies. The countries of Bulgaria, Croatia, Czechia, Estonia, Hungary, Latvia, Lithuania, Poland, Romania, Slovak Republic, and Slovenia, which are included in the sample of the analysis conducted in this study, have all experienced this process. The role of the State in the development of the free market economy and financial markets, which gained momentum especially after the $1990 \mathrm{~s}$, has been both a curiosity and an important research area. The following questions were put forward: What is the level of development in financial markets with the transition to a free-market economy in these countries? How has the development of financial markets affected other areas of the economy? What is the level of State intervention in the economy? How does this intervention affect the economy? However, the focus of this study is to answer to what extent the implementation 
results of the government's domestic debt policy have short- and long-term effects on financial markets.

From this point of view, the countries included in this analysis are determined as Bulgaria, Croatia, Czechia, Estonia, Hungary, Latvia, Lithuania, Poland, Romania, Slovak Republic, and Slovenia. With the EU membership of these countries, integration into the free market and capitalist order has accelerated. Except for Slovenia, the national income classification realized by the World Bank for most of these countries remained at the lower middle-income (LM) and upper middle-income (UM) levels until 2005. From these countries, Romania reached the upper middle-income level in 2020. Figure 1 and Figure 2 show the course of the financial development index with the variable domestic bank credit to the government as a percent of GDP, which represents the public debt in these countries.

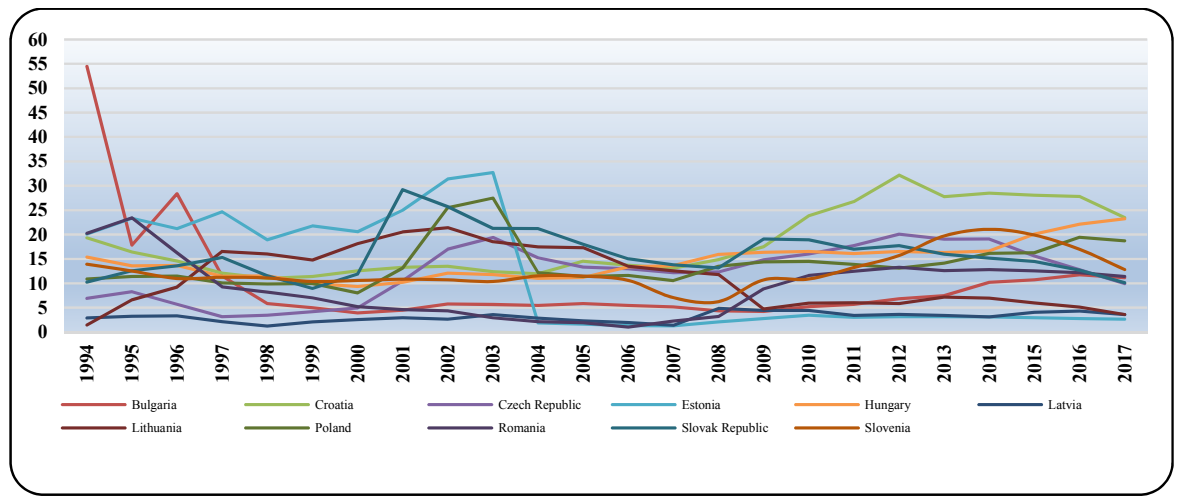

Figure 1. Credit by domestic money banks to the government (of GDP\%)

In Figure 1, public debt levels in the Central and Eastern European economies within the scope of this study are included. The figure shows the ratio of credit by the domestic banks to the government to GDP for the period between 1994 and 2017. Considering the average of the period 1994 to 2017, the country with the highest public domestic debt among the countries is Croatia with $18 \%$, and the country with the lowest public debt is Latvia with $3 \%$. The public debt ratios of the countries compared with the average between 1994 and 2017, from the highest to the lowest, are as follows: Croatia, 18\%; Slovak Republic, 15\%; Hungary, 15\%; Poland, 14\%; Slovenia, 13\%; the Czechia, 12\%; Estonia, 11\%; Lithuania, 11\%; Bulgaria, 11\%; Romania, 9\%; and Latvia, 3\%. Grosu et al. (2021) showed that only a few of these countries have pursued sustainable public debt policies. Considering the period of 1994 to 2017, the countries whose public debt level decreased from 1994 to 2017 are Bulgaria, Estonia, Romania, Slovak Republic, and Slovenia. Public domestic borrowing mainly depends on the economic structure of countries, such as financial development levels, debt structures, inflation, and so on. 
Does Domestic Public Debt Affect Financial Development? New Evidence from Central and Eastern European Economies

However, it also varies politically in many countries. Therefore, public debt differs in developed countries. For example, considering the average of 1994 to 2017 according to the World Development Indicators data, public debt was 33\% in Belgium, $9 \%$ in Denmark, $17 \%$ in France, 30\% in Germany, $7 \%$ in the United States, and 3\% in the United Kingdom. Although these rates vary according to the economic policies of developed countries, the public domestic debt ratios of the countries included in this research are generally at a high level.

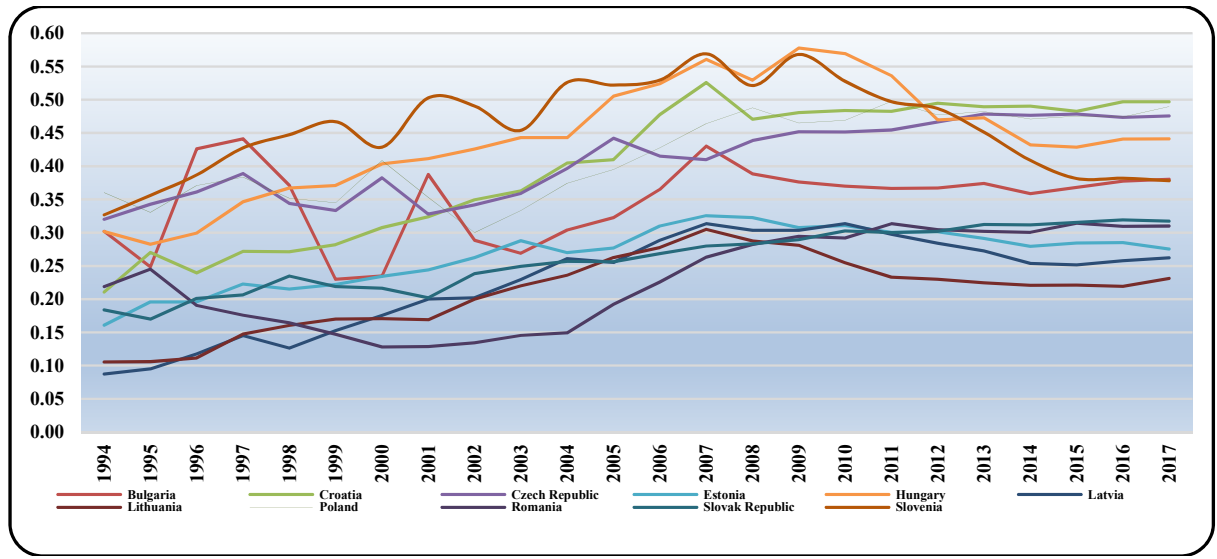

Figure 2. Financial Development Index

Figure 2 shows the financial development index of the countries for the period between 1994 and 2017. In transition economies that have adopted the free market economy since the early 1990s and accelerated this process with EU integration, the financial development index has continuously increased. In the period from 1994 to 2017, the country with the least increase is Slovenia with 15\%, and the country with the highest increase in Latvia with 199\%. During this period, the average rate of increase of the countries is $73 \%$. When the financial development index is evaluated based on countries, the average of countries for the period 1994 to 2017 is as follows: Slovenia, 46\%; Hungary, 44\%; Poland, 42\%; the Czechia, 41\%; Croatia, 40\%; Bulgaria, 35\%; Estonia, 27\%; the Slovak Republic, $26 \%$; Romania, 23\%; Latvia, 23\%; Lithuania, $21 \%$. It cannot be stated that the financial development levels of these countries, in general, are higher when compared with developed countries. For example, according to the IMF data, the averages for the 1994 to 2017 period are as follows: Belgium, 65\%; Denmark, 69\%; France, 77\%; Germany, 78\%; United States, $89 \%$; and the United Kingdom, $86 \%$. The financial development levels of these countries are quite high. It can be stated that the factors affecting the financial development levels of the countries examined in this study should be determined, and economic policies should be 
designed accordingly. Because Bua et al. (2014) showed that in countries with low financial depth and financial development, public borrowing may have a greater impact on financial development.

\section{Theoretical Framework and Literature Review}

According to the empirical and theoretical literature, the effect of the State on financial markets will not always be positive through borrowing. The effect of public debt on financial markets is explained by two main views. The first of these is the "lazy banks" view developed by Hauner $(2008,2009)$ based on the crowding-out effect. The "lazy banks" view argues that the banks' tendency to secure resources causes banks to disrupt their other functions and reduce their desire to develop more risky financial products. The second approach is the "safe assets" view. The "safe assets" view argues that the increases in public debt will positively affect financial development as banks keep secure assets compared with the private sector.

The effect of public expenditures on domestic and external borrowing is based on the fund demand created by the government because of budget deficits and, therefore, the rise in real interest rates because governments frequently resort to public borrowing to finance increased public expenditures. Considering that the level of domestic borrowing is high among the borrowing combinations especially in developing countries, the increase in the domestic borrowing levels of the states causes a decrease in the funds that can be given to the private sector. Therefore, this situation of the private sector, which cannot effectively access available funds, causes a decrease in consumption and investments (Caballero and Krishnamurthy, 2004; Panizza, 2008; Hauner, 2008; Hauner, 2009; Ismihan and Ozkan, 2012). This situation, where real interest rates increase because of public domestic debt and thus investments decrease, is known as the crowding-out effect. According to the crowding-out effect approach, public domestic borrowing adversely affects financial development and the economy for various reasons. Among these reasons are increasing real interest rates, increasing the cost of capital, reducing private investments, decreasing growth and welfare, which adversely affect the private sector credit market, absorb public revenues, negatively affect the sustainability of external borrowing because of the "domestic original Sin" hypothesis, and adversely affect debt service due to debt structure (Guscina, 2008; Abbas and Christensen, 2010; Ersoy, 2012).

This situation is important not only for developing and transition economies but also for developed countries (Kumhof and Tanner, 2005). In the literature, there is the "lazy banks" view put forward by Hauner $(2008,2009)$ that supports the crowding-out effect. Indicating the main effect of public debt on financial markets, "lazy banks" argues that the banks' tendency to secure resources will cause the banks to disrupt their other functions and reduce their desire to develop more risky financial products (Emran and Farazi, 2009). In this case, the 
Does Domestic Public Debt Affect Financial Development? New Evidence from Central and Eastern European Economies

banking sector and, therefore, financial development are negatively affected. In addition to these two main effects, the fact that banks tend to use government bonds instead of private-sector loans because of their liquidity advantage in high inflation periods supports the lazy banks' view (Sekmen et al., 2020). Besides the lazy banks' view, the main arguments of those who oppose public domestic borrowing are the crowding-out effect, the risky nature of public domestic borrowing, and the negative effect of cost inefficiency of public domestic borrowing on banks (Ersoy, 2012). Remember that the lazy banks view stems from the funding of the financial system to meet the financial needs of the State. The positive effect of public borrowing on financial markets is explained by the "safe assets" view. The safe assets view argues that increases in public domestic debt will positively affect financial development as banks keep secure assets compared with the private sector. Government bonds are a safe asset in the financial sector for developing countries and transition economies (Kumhof and Tanner, 2005). In this way, the financial risks of domestic banks will decrease, and the overall speed of financial development will increase. Many studies in the literature defend this view because of various factors. These factors are, for example, public domestic borrowing instruments facilitate banks' lending potential, increase investments, increase total factor productivity and investment efficiency, provide liquidity to the system, reduce the informal economy by recording economic activities, and provide infrastructure for derivatives markets. It can also be added to this list that it sets a benchmark for prices in private-sector bond markets, increases household savings, and increases the tax base because of all these developments (Kumhof and Tanner, 2005; Ersoy, 2012). Apart from other positive developments in the economy through public domestic borrowing, it is argued that the increase in the profitability of banks increases the willingness of banks to offer loans to the financial system (Kumhof and Taner, 2005). In this case, financial development will be positively affected.

Although empirical studies in the literature are limited, pioneering studies were carried out by Hauner $(2008,2009)$. In these studies, Hauner (2008) found that public domestic debt negatively affects the banking sector performance in developing countries. The findings of Hauner (2009) in his study on 73 middleincome countries support the "lazy banks" view put forward by him. It has been revealed that the loans given by banks negatively affect the profitability, efficiency, and financial development of banks. Kumhof and Taner (2005) found that public debt is preferred as a safe option in developing countries where institutional and legal infrastructure is weak, but this preference negatively affects the financial system. When empirical studies are evaluated in general, many studies determine the negative effect of public domestic borrowing on financial development (Christensen, 2004; Ersoy, 2012; Altayligil and Akkay, 2013; Mun and İsmail, 2015; İlgün, 2016). Nevertheless, some studies determine the relationship between public debt and financial development positively. For example, Kutivadze (2011) 
and Sekmen et al. (2020) found that public domestic debt positively affected financial development. The results obtained in these studies support the safe assets view. Although the financial development variable is not used in some studies, the effects of public borrowing on the amount of credit provided by domestic banks and the crowding-out effect caused by public borrowing have been examined (Emran and Farazi, 2009; Caballero and Krishnamurthy, 2004; Bua et al., 2014; Ismihan and Ozkan, 2012; Anyanwu et al., 2017). In recent years, there has been an increasing amount of literature. Kabir and Flath (2020) determined the negative impact of public debt on financial development, whereas Sekmen et al. (2020) reached the opposite conclusion. Moreover, the number of studies that reveal the relationship between public debt and financial development based on EU countries is very limited in the literature. Janda and Kravtsov (2017) analyzed the effects of public debt on financial development and banking for 26 Central and Eastern European countries between 1995 and 2014 using panel data analysis. The results of the study show that public domestic debt has a positive effect on banking performance in the short term and harms the loans extended to the private sector in the medium and long terms. The results of the abovementioned studies reveal that the relationship between public domestic debt and financial development differs. This difference is because of the period examined, country(s), and methods used in these studies. This study aims to reveal the effects of public domestic debt on financial development in the Central and Eastern European economies between 1994 and 2017 in the short and long terms. As such, this study aims to fill the gap in the literature.

\section{Data and Empirical Methodology}

The analysis was based on a cross-country panel data set consisting of 11 Central and Eastern European countries (Bulgaria, Croatia, Czechia, Estonia, Hungary, Latvia, Lithuania, Poland, Romania, Slovak Republic, and Slovenia) for the period of 1994 to 2017. Estimation model was conducted to analyze the relationship between public debt and financial development in these countries, based on the studies, such as Hauner (2009), İlgün (2016), Kabir and Flath (2020), and Sekmen et al. (2020). According to the empirical and theoretical literature, whereas the financial development index $(f d)$ is taken as the dependent variable, public debt $(d e b t)$ is taken as the independent variable. Many variables are used as a proxy of financial development in empirical studies. International Monetary Fund (IMF) Financial Institutions calculate the financial development index, which shows the financial development of countries, considering the depth, accessibility, and efficiency of financial markets. The financial development index consisting of sub-components is also frequently used in the literature. In this study, considering the simplicity and readability of the analysis, the financial development index was preferred instead of sub-indices. These data have been derived from the IMF database. Considering the studies of Hauner (2009), İlgün (2016), and Kabir and 
Does Domestic Public Debt Affect Financial Development? New Evidence from Central and Eastern European Economies

Flath (2020), the variable credit by domestic money banks to the government and state-owned enterprises as a percent of GDP is included in the model as a proxy of public domestic debt and derived from the World Bank Global Financial Development Database (GFDD).

In this study, the relationship between public debt and financial development in 11 Central and Eastern European countries was analyzed using the panel data method. In the first part of the analysis, the existence of a long-term relationship between public debt and financial development was determined. In the second part, long- and short-term coefficients between variables were estimated. The existence of a long-term relationship was determined by panel cointegration tests. To ensure that the model to be predicted is efficient and consistent or to avoid the risk of spurious regression, the stationary degrees of the variables were determined first. Because the stationarities of the series vary according to the crosssection dependency of the variables, the cross-sectional dependencies of the series were determined by the Breusch and Pagan (1980) $\mathrm{CD}_{\mathrm{LM} 1}$ test, since the time dimension of the data set $(\mathrm{T}=24)$ is higher than the cross-sectional dimension of the data set $(\mathrm{N}=11)$. After determining the stationarity and cross-section dependency of the variables, the existence of long-term relationships between variables was determined by cointegration tests. Cointegration tests differ depending on the stationarity levels of the series, the cross-sectional dependency, and whether the slope coefficients of the cointegration model are homogeneous. Therefore, the homogeneity of the coefficients in the cointegration equation was determined by the Pesaran and Yamagata (2008) Delta Test, whereas the cross-sectional dependence of the cointegration model was determined by the Breusch and Pagan (1980) $\mathrm{CD}_{\mathrm{LM} 1}$ test.

After this stage of the analysis, the cointegration coefficients of the estimated models were estimated. The cointegration coefficients were estimated by pooled mean group estimator (PMG), mean group estimator (MG), and dynamic fixed effects estimator (DFE) methods based on the panel ARDL model. The estimation equation for the long-term relationship between financial development and public debt using the panel ARDL method is shown in Equation 1.

$$
f d_{i t}=\sum_{k=1}^{p} \emptyset_{i k} f d_{i, t-k}+\sum_{k=0}^{n} \gamma_{i k} d e b t_{i, t-k}+\mu_{i t}+e_{i t}
$$

In Equations 1 and 2, $p$ and $n$ represent the lag lengths. $\gamma_{i k}$ and $\emptyset_{i k}$ represent the long-run coefficients of financial development and public debt variables; $\mu_{i t}$ is the unit effects, and $e_{i t}$ is the error term, respectively.

$\Delta f d_{i t}=\varphi_{i}\left(\Delta f d_{i, t-1}-\gamma_{t} f d_{i t}\right)+\sum_{k=1}^{p-1} \sigma_{i k} \Delta f d_{i, t-k}+\sum_{k=0}^{n-1} \delta_{i k} \Delta d e b t_{i, t-k}+\mu_{i t}+e_{i t}$ 
The optimal lag length of panel ARDL $(1,1)$ was chosen for PMG estimations following the Schwarz information criterion (SIC). In the literature, tests that determine the cointegration relationship developed by Pedroni (1995) require that all variables included in the analysis be stationary in their differences. However, in the panel ARDL method, the long-term relationship was determined according to the alternative hypotheses specified in Equation 3 that shows there is no cointegration relationship between variables. Equation 4 shows there is a cointegration relationship between variables.

$$
\begin{aligned}
& H_{0}: \gamma_{1 i}=\gamma_{2 i}=0 \\
& H_{1}: \gamma_{1 i} \neq \gamma_{2 i} \neq 0
\end{aligned}
$$

Critical values determined by Pesaran et al. (2001) were considered in hypothesis tests based on Fisher statistics and Wald statistics based on boundary test approaches. If the statistical values calculated in the panel ARDL method are greater than the critical value of the $\mathrm{F}$ statistic, the $\mathrm{H}_{0}$ hypothesis is rejected. After this stage of the analysis, the long-term equation was estimated. The long-term prediction model is shown in Equation 2. The error correction of the model was also estimated, and the short-term relationship [EC] was obtained. The estimated error correction model is shown in Equation 5.

$\Delta f d_{i t}=\alpha_{1 i}+\sum_{k=1}^{p-1} \beta_{1 i k} \Delta f d_{i, t-k}+\sum_{k=0}^{n-1} \beta_{2 i k} \Delta d e b t_{i, t-k}+\eta 1 \mathrm{i} E C_{1, i t-1}+e_{i t}$

Equation 5 estimates the short-term balance between variables and the error correction term. When the error correction term $E C_{1, i t-1}$ is negative and statistically significant, short- and long-term coefficients can be interpreted. The residues $e_{i t}$ in Equation 5 were assumed to be equally independent and normally distributed with zero mean and constant variance. Among the estimators based on the panel ARDL model, the pooled mean group (PMG) estimator developed by Pesaran (1999) is frequently used in the literature. The PMG estimator allows for long-term homogeneity and short-run heterogeneity in constants and parameters. Therefore, the coefficients obtained from PMG estimators have asymptotic and normal distribution (Pesaran et al., 1999). In this study, the PMG estimator was preferred for long-term and short-term coefficient estimation.

\section{Results and Discussion}

In the first step of the analysis carried out in the study, the stability levels and cross-section dependencies of the variables were determined. Panel unit root tests vary according to the cross-sectional dependencies of the variables. Therefore, initially, the cross-section dependencies of variables were determined by the $\mathrm{CD}_{\mathrm{LM}}$ test introduced by Breusch and Pagan (1980). The $\mathrm{CD}_{\mathrm{LM} 1}$ test results show that there was cross-sectional dependency among the variables. Because there is a 
Does Domestic Public Debt Affect Financial Development? New Evidence from Central and Eastern European Economies

cross-sectional dependency in series, the stationarities of the series were determined by the Pesaran (2007) Cross- Sectionally Augmented Dickey-Fuller (CADF) unit root test considering cross-sectional dependency. Second-generation panel unit root test results are shown in Table 2. Results show that all of the variables were stationary at the first difference.

Table 2. Results of Panel Unit Root Test and Cross Section Dependence Test $C D_{L M 1}$ Test Results $\left(H_{0:}\right.$ There is cross-sectional dependency)

\begin{tabular}{|c|c|c|}
\hline Variable & t statistics & p-value \\
\hline$f d$ & 642.4823 & 0.000 \\
\hline$d e b t$ & 251.1692 & 0.000 \\
\hline Results of Panel Unit Root Test
\end{tabular}

\begin{tabular}{|c|c|c|c|c|c|c|c|c|}
\hline & & $\operatorname{lags}$ & $t$-bar & $c v 10$ & $c v 5$ & $c v 10$ & $Z[t-b a r]$ & p-value \\
\hline \multirow{2}{*}{$f d$} & \multirow{2}{*}{ Constant } & 0 & -2.021 & -2.140 & -2.250 & -2.450 & -0.859 & 0.195 \\
\hline & & 1 & -1.843 & -2.140 & -2.250 & -2.450 & -0.249 & 0.402 \\
\hline \multirow{2}{*}{$f d$} & \multirow{2}{*}{ Constant and Trend } & 0 & -2.440 & -2.140 & -2.250 & -2.450 & -2.290 & 0.011 \\
\hline & & 1 & -2.294 & -2.660 & -2.760 & -2.960 & 0.093 & 0.537 \\
\hline \multirow{2}{*}{$\Delta f d$} & \multirow{2}{*}{ Constant } & 0 & -5.204 & -2.140 & -2.250 & -2.450 & -11.741 & 0.000 \\
\hline & & 1 & -3.628 & -2.140 & -2.250 & -2.450 & -6.353 & 0.000 \\
\hline \multirow{2}{*}{$\Delta f d$} & \multirow{2}{*}{ Constant and Trend } & 0 & -5.577 & -2.660 & -2.760 & -2.960 & -11.615 & 0.000 \\
\hline & & 1 & -4.381 & -2.660 & -2.760 & -2.960 & -7.351 & 0.000 \\
\hline \multirow{2}{*}{ debt } & \multirow{2}{*}{ Constant } & 0 & -1.621 & -2.140 & -2.250 & -2.450 & 0.510 & 0.695 \\
\hline & & 1 & -1.353 & -2.140 & -2.250 & -2.450 & 1.426 & 0.923 \\
\hline \multirow{2}{*}{ debt } & \multirow{2}{*}{ Constant and Trend } & 0 & -2.374 & -2.660 & -2.760 & -2.960 & -0.194 & 0.423 \\
\hline & & 1 & -2.154 & -2.660 & -2.760 & -2.960 & 0.594 & 0.724 \\
\hline \multirow{2}{*}{$\Delta d e b t$} & \multirow{2}{*}{ Constant } & 0 & -4.032 & -2.140 & -2.250 & -2.450 & -7.733 & 0.000 \\
\hline & & 1 & -2.866 & -2.140 & -2.250 & -2.450 & -3.748 & 0.000 \\
\hline \multirow{2}{*}{ debt } & \multirow{2}{*}{ Constant and Trend } & 0 & -4.134 & -2.660 & -2.760 & -2.960 & -6.470 & 0.000 \\
\hline & & 1 & -3.095 & -2.660 & -2.760 & -2.960 & -2.764 & 0.003 \\
\hline
\end{tabular}

After determining the cross-sectional dependencies and stationarity levels of the series, a cointegration test was used to determine the existence of a longterm relationship. Cointegration tests depend on the cross-section dependence of the estimated models and the homogeneity of the slope coefficients in cointegration model. Therefore, the homogeneity of the coefficients in the cointegration equation was determined by the Pesaran and Yamagata (2008) Delta Test, whereas the cross-section dependence of the cointegration model was determined by the Breusch and Pagan (1980) $\mathrm{CD}_{\mathrm{LM} 1}$ test. Test results are summarized in Table 3. According to the test results, the existence of cross-sectional dependency in cointegration model and the slope coefficients in the model were heterogeneous. 
Ersin Nail Sağdiç, Fazlı Yildiz, Taner Güney

Table 3. Homogeneity and Cointegration Test Results

\begin{tabular}{|c|c|c|c|}
\hline & & Statistic & $\mathrm{p}$-value \\
\hline $\begin{array}{c}\text { Homogeneity } \\
\left(\mathrm{H}_{0}: \text { Slope coefficients are }\right. \\
\text { homogenous })\end{array}$ & $\begin{array}{l}\text { Delta Tilde } \\
\text { Delta Tilde adj }\end{array}$ & $\begin{array}{r}1.720 \\
-1.409\end{array}$ & $\begin{array}{l}0.043 \\
0.033\end{array}$ \\
\hline Cross-sectioanel Depence (Model) & $\mathrm{CD}_{\mathrm{LM} 1}$ & 80.657 & 0.014 \\
\hline \multicolumn{4}{|c|}{ Cointegration Test Results (LM Bootstrap) } \\
\hline & $\begin{array}{l}\text { Statistic } \\
2.938\end{array}$ & $\begin{array}{l}\text { Asymptotic } \\
\text { p-value } \\
0.082\end{array}$ & $\begin{array}{c}\text { Bootstrap p-value } \\
0.178\end{array}$ \\
\hline
\end{tabular}

Hence, the cointegration relationship between variables was tested with Westerlund and Edgerton (2007) LM Bootstrap Cointegration Test considering cross-sectional dependence and heterogeneity. Table 3 summarizes the cointegration test results. According to the LM bootstrap cointegration test result, the null hypothesis that there is a long-term relationship between variables is accepted. Based on this result, it was determined that there is a long-term relationship between the financial development level and public domestic debt between 1994 and 2017 in Central and Eastern European countries. PMG estimator based on panel ARDL method was used for long- and short-term estimations between public domestic debt and financial development. Long- and short-term coefficients between financial development and public domestic debt based on the PMG estimator are presented in Table 4.

Table 4. Results of Long and Short Term Coefficients of PMG

\begin{tabular}{|c|c|c|c|c|}
\hline \multicolumn{5}{|c|}{ Results of PANEL } \\
\hline \multicolumn{2}{|c|}{$\begin{array}{c}\text { Long Term } \\
(\text { debt }) \\
\end{array}$} & $\left(\varphi_{i}\right)$ & \multicolumn{2}{|c|}{$\begin{array}{c}\text { Short Term } \\
(\Delta d e b t)\end{array}$} \\
\hline \multicolumn{2}{|c|}{$-0.457(0.000)$} & $-0.093(0.087)$ & \multicolumn{2}{|c|}{$-0.073(0.076)$} \\
\hline \multicolumn{5}{|c|}{ Hausman Test : $M G-P M G=0.00(0.63)$} \\
\hline \multicolumn{5}{|c|}{ Short Term Coefficients for Countries (PMG) } \\
\hline Country & \multicolumn{2}{|c|}{$\mathrm{EC}\left(\varphi_{i}\right)$} & \multicolumn{2}{|c|}{$\Delta d e b t$} \\
\hline Bulgaria & -0.6170 & 0.000 & 0.0407 & 0.004 \\
\hline Croatia & -0.1449 & 0.000 & -0.1259 & 0.000 \\
\hline Czechia & -0.0007 & 0.000 & 0.0474 & 0.000 \\
\hline Estonia & -0.0615 & 0.000 & -0.2291 & 0.000 \\
\hline Hungary & -0.0607 & 0.000 & 0.2272 & 0.009 \\
\hline Latvia & -0.0391 & 0.000 & -0.0418 & 0.000 \\
\hline Lithuania & -0.0437 & 0.000 & -0.1489 & 0.000 \\
\hline Poland & 0.0610 & 0.000 & -0.2267 & 0.000 \\
\hline Romania & -0.0684 & 0.000 & -0.1185 & 0.000 \\
\hline Slovak Republic & -0.0215 & 0.010 & -0.0709 & 0.000 \\
\hline Slovenia & -0.0443 & 0.000 & -0.1588 & 0.000 \\
\hline
\end{tabular}

Note: $\varphi_{i}$ is the error correction term. 
Does Domestic Public Debt Affect Financial Development? New Evidence from Central and Eastern European Economies

From the results obtained from the PMG estimator, public domestic debt has a negative and statistically significant effect on financial development in both the short and long terms between 1994 and 2017 in Central and Eastern European countries. The fact that the error term is negative and statistically significant indicates that the public domestic debt harms the financial development level in the short run, and at the same time, deviations due to the stationary series will stabilize in the long run. The results obtained support the cointegration test results. Longterm coefficient results show that financial development decreases approximately $0.45 \%$ as public domestic debt increases $1 \%$. In the short term, an increase of $1 \%$ in public domestic debt decreases the level of financial development by $0.073 \%$. The negative impact of public domestic debt on the financial development level in the relevant countries is more effective in the long run, although it is also effective in the short term. Error correction terms are significant and negative at the country level in all countries except Poland. In the short run, whereas public domestic debt harms the financial development level throughout the panel, it is seen that this effect is positive in other countries, such as Bulgaria, Czechia, and Hungary. In other countries, it has been determined that public domestic debt harms financial development in both the short and long terms. These results are consistent with the results of the study by Janda and Kravtsov (2017) for Central and Eastern European countries.

\section{Conclusions and Policy Recommendations}

In this study, the relationship between public debt and financial development in 11 Central and Eastern European countries was investigated using the panel data method. Before determining the existence of a long-term relationship between public debt and financial development with the cointegration test, the cross-section dependence of the variables and the cointegration model, the stationarities of the variables, the homogeneity of the slope coefficients in the cointegration model were determined first. The cointegration test results show the existence of a long-term relationship between public domestic debt and financial development in these countries for the period of 1994 to 2017. The estimation of the short- and long-term coefficients was determined by the PMG estimator based on the panel ARDL model. According to the results obtained from the PMG estimator, it is determined that public debt harms financial development in both the short and long terms throughout the panel. The determination of the error term as negative and statistically significant indicates that public domestic debt harms the financial development level in the short run, and deviations because of the stagnation of the series will stabilize in the long run. Long-term coefficient results show that financial development decreases approximately $0.45 \%$ as public domestic debt increases $1 \%$. In the short term, an increase of $1 \%$ in public domestic 
debt decreases the level of financial development by $0.073 \%$. Based on this, it has been concluded that public domestic debt is more effective in the long term for the relevant countries. These results are consistent with the literature and confirms the results obtained by Janda and Kravtsov (2017). The results also support the "crowding-out" and "lazy banks" views, which indicate the negative impact of public debt on financial markets in Central and Eastern European countries. The increase in public domestic debt from the banking sector will adversely affect the development of financial development and financial depth by reducing the volume of loans to be made available to the private sector. In this framework, there will be a crowding-out effect from public borrowing, which replaces private sector borrowing in the loan portfolios of the banking sector. Considering that the financial markets in the Central and Eastern European countries started to form in the 1980s and began to deepen in parallel with the international financial markets after the 2000s, it can be concluded that the financial markets in these countries were negatively affected by the fiscal policies and economic interventions of the State. In this process supported by effective monetary policies, States frequently resort to public debt to gain the depth of the bond markets and therefore, the financial markets. However, although this strategy was expected to support financial development in Central and Eastern European countries, it made the banking system in these countries lazy. Therefore, the diversity of financial products has decreased, and financial assets have not developed and financial markets have not deepened and the speed of financial development slows down.

The coefficient results obtained in the short term appear to be positive in Bulgaria, Czechia, and Hungary. It has been determined that in these countries, public domestic debt contributes to the development of financial markets in the short term. The results support the theoretical short-term "safe assets" view. It is noteworthy that the financial development index in these countries is higher than the other countries included in the analysis. From this point of view, secure assets provided by the State in the relevant countries have had a positive impact on financial markets in the short term. This situation has many reasons. First of all, macroeconomic policies implemented in the adaptation process to the free market economy may be the main reason for this situation. In the literature, factors such as high inflation, the frequency of sudden inflows and outflows of foreign capital, the need for external funding, institutional and regulatory factors, economic growth, political factors, and the level of democracy, constitute an important area of research, and that may be the main factors affecting the development of financial markets in these countries. Also, the weakening of the effectiveness of fiscal policy instruments and policies covering public expenditures, public revenues, and public borrowing policies that diverge from fiscal discipline causes adverse effects on financial markets due to deteriorating budget financing. Because of similar adaptation problems in transition economies, these factors may have an impact on financial markets. Generally, these results are important in terms of showing the negative impact of government interventions in the economic field through public 
Does Domestic Public Debt Affect Financial Development? New Evidence from Central and Eastern European Economies

domestic borrowing in transition economies on financial markets. In future studies on this subject, it is necessary to focus on how the institutional and regulatory factors, macroeconomic factors, and financial factors of transition economy countries can affect the financial markets of the countries.

\section{REFERENCES}

[1] Altaylıgil, Y.B., Akkay, R.C. (2013), The Effect of The Domestic Debt on The Financial Development: A Case Study For Turkey. International Journal of Economics and Finance, 5(5): 64-74;

[2] Anyanwu, A., Gan, C., Hu, B. (2017), Government Domestic Debt, Private Sector Credit, and Crowding Out Effect in Oil-Dependent Countries. Journal of Economic Research, 22: 127-151;

[3] Aschauer, D.A. (1989), Does Public Capital Crowd Out Private Capital?. Journal of Monetary Economics, 24(2): 171-188;

[4] Bua, G., Pradelli, J., Presbito, A.F. (2014), Domestic Public Debt in LowIncome Countries Trends and Structure. Review of Development Finance, 4: 119 ;

[5] Breusch, T.S., Pagan, A.R. (1980), The Lagrange Multiplier Test and Its Applications to Model Specification in Econometrics. The Review of Economic Studies, 47(1): 239-253;

[6] Caballlero, R., Krishnamurthy, A. (2004), Fiscal Policy and Financial Depth. NBER Working Paper, No: 10532;

[7] Christensen, J. (2004), Domestic Debt Markets in Sub-Saharan Africa. IMF Working Paper, No:04/46;

[8] Emran, M.S., Farazi, S. (2009), Lazy Banks? Government Borrowing and Private Credit in Developing Countries. Retrieved from https://ssrn.com/ abstract=1418145;

[9] Ersoy, İ. (2012), Government Debt vs. Financial Depth Dilemma in Developing Countries: The Case of Turkey. Acta Oeconomica, 62(3): 345-362; [10] Grosu, A.C., Pintilescu, C., Zugravu, B. (2021), Trends in Public Debt Sustainability in Central and Eastern EU Countries. Post-communist Economies; [11] Hauner, D. (2008), Credit to Government and Banking Sector Performance. Journal of Banking \& Finance, 32:1449-1507;

[12] Hauner, D. (2009), Credit to Government and Banking Sector Performance. Journal of Development Economics, 88:171-183;

[13] Ismıhan, M., Ozkan, F.G. (2012), Public Debt and Financial Development: A Theoretical Exploration. Economics Letters, 115:348-351;

[14] İlgün, M.F. (2016), Financial Development and Domestic Public Debt in Emerging Economies: A Panel Cointegration Analysis. Journal of Applied Economics and Business Research, 6(4):284-296; 
[15] Janda, K., Kravtsov, O. (2017), Time-varying Effects of Public Debt on the Financial and Banking Development in the Central and Eastern Europe. Munich Personal RePec Archive, No. 77325;

[16] Kabir, R., Flath, D. (2020), Crowding Out of Private Credit Caused by Government Borrowing from the Domestic Banking Sector: New Cross-Country Estimates and a Novel Interpretation. Social Systems Studies, 41:183-208; [17] Kumhof, M., Tanner, E. (2005), Government Debt: A Key Role in Financial Intermediation. IMF Working Paper, No:05/57;

[18] Kutivadze, N. (2011), Public Debt and Financial Development. Universita Degli Studi Di Milano Working Paper, No:13;

[19] Mun, M.W., Ismail, N.W. (2015), The Impact of Domestic Public Debt on Financial Development in Malaysia. International Journal of Social Science Research, 3(2): 1-19;

[20] Panizza, U. (2008), Domestic and External Public Debt in Developing Countries. UNCTAD Discussion Papers No. 188.

[21] Pedroni, P. (1995), Panel Cointegration: Asymptotic and Finite Sample Properties of Pooled Time Series Tests, with An Application to The PPP Hypothesis. Indiana University Working Papers in Economics, No: 95-013; [22] Pesaran, M.H. (2007), A Simple Panel Unit Root Test in the Presence of Cross-Section Dependence. Journal of Applied Econometrics, 2(2): 265-312. [23] Pesaran, M.H., Shin, Y., Smith, R.P. (1999), Pooled Mean Group Estimation of Dynamic Heterogeneous Panels. Journal of the American Statistical Association, 94: 621-634;

[24] Pesaran M.H., Shin Y., Smith R.J. (2001), Bounds Testing Approaches to the Analysis of Level. Relationships Journal of Applied Econometrics, 16(3):289326 ;

[25] Pesaran M.H., Yamagata, T. (2008). Testing Slope Homogeneity in Large Panels. Journal of Econometrics, 142:50-93;

[26] Sekmen T., Doğan E., Topuz S.G. (2020), The Crowding out Effect of Domestic Public Debt on Financial Development in Turkey. Journal of Yasar University, 15(59):544-559;

[27] Wang, Y., Cheng, L., Wang, H., Li, L. (2014), Institutional Quality, Financial Development and OFDI. Pacific Science Review, 16(2): 127-132; [28] Westerlund, J., Edgerton, D.L. (2007). A Panel Bootstrap Cointegration Test. Economics Letters, 97:185-190. 